\title{
Threonine affects digestion capacity and hepatopancreatic gene expression of juvenile blunt snout bream (Megalobrama amblycephala)
}

\author{
Habte-Michael Habte-Tsion ${ }^{1,2} \dagger$, Mingchun Ren $^{1,3}$, Bo Liu ${ }^{1,3}$, Jun Xie ${ }^{1,3}$, Xianping Ge ${ }^{1,3 *}$, Ruli Chen ${ }^{3}$, \\ Qunlan Zhou ${ }^{1,3}$ and Liangkun Pan $^{3}$ \\ ${ }^{1}$ Wuxi Fisheries College, Nanjing Agricultural University, Shanshui East Road No. 9, Wuxi, Jiangsu 214081, \\ People's Republic of China \\ ${ }^{2}$ Ministry of Marine Resources the State of Eritrea, PO Box 27, Massawa, Eritrea \\ ${ }^{3}$ Key Laboratory for Genetic Breeding of Aquatic Animals and Aquaculture Biology, Freshwater Fisheries Research Center, \\ Chinese Academy of Fishery Sciences, Shanshui East Road No. 9, Wuxi, Jiangsu 214081, People's Republic of China
}

(Submitted 10 January 2015 - Final revision received 20 May 2015 - Accepted 22 May 2015 - First published online 23 July 2015)

\section{Abstract}

The present study conducted a 9-week feeding trial to investigate the effects of threonine (Thr) on the digestion capacity and hepatopancreas gene expression of juvenile blunt snout bream (Megalobrama amblycephala). For this purpose, three tanks (300 litres/tank) were randomly arranged and assigned to each experimental diet. Juvenile fish were fed with diets containing graded Thr levels (0.58, 1.08, $1.58,2.08$ or $2.58 \%$ of the diet) to apparent satiation four times daily. At the end of the feeding trial, the results indicated that hepatopancreas weight, hepatosomatic index, hepatopancreatic protein content, intestinal weight, intestosomatic index and intestinal protein content increased with increasing dietary Thr levels up to $1.58 \%$ and thereafter decreased $(P<0.05)$. The activities of chymotrypsin, trypsin, amylase and lipase elevated as dietary Thr levels increased up to $1.58 \%(P<0.05)$, while these activities decreased in most cases after $1.58 \%$ dietary Thr except for chymotrypsin and trypsin in the hepatopancreas (plateau 1.58-2.08\% Thr). The relative gene expression levels of chymotrypsin, trypsin, amylase, lipase, target of rapamycin and insulin-like growth factor-I were up-regulated, and the highest values were observed with $1.58 \%$ dietary Thr or 1.58 and $2.08 \%$ dietary Thr, whereas the relative gene expression levels of eukaryotic translation initiation factor 4E-binding protein 2 gradually decreased $(P<0.10)$ as dietary Thr levels increased up to $1.58 \%$ and thereafter significantly increased $(P<0.05)$, which could explain that about $1.58 \%$ dietary Thr could improve the growth and development of digestive organs and activities of digestive enzymes of juvenile blunt snout bream.

Key words: Blunt snout bream: Threonine: Digestive enzyme activities: Gene expression: Target of rapamycin pathway

Blunt snout bream (Megalobrama amblycephala) is a major cultured freshwater fish species in China, also introduced in North America (northern Canada to southern Mexico), Africa and Euro-Asia ${ }^{(1,2)}$. Blunt snout bream has great consumer demand in China, and its production has been rapidly increased and reached approximately 0.70 million tons in $2012^{(3)}$. This fish species has a bright future in aquaculture worldwide because of its adaptability to the local environment, compatibility with native species, being a good candidate for freshwater intensive culture, fast growth, high larval survival rate, tender flesh, and disease resistance ${ }^{(4)}$. However, few nutritional studies have reported about this species including three amino acids, such as dietary threonine $(\mathrm{Thr})^{(5,6)}$, arginine ${ }^{(7)}$ and methionine ${ }^{(8)}$.

Thr is the third essential amino acid for growing fish fed with low-protein diets, and involved in many physiological and biochemical processes, including growth, feed efficiency, immune function, and maintenance of adequate feed intake $e^{(5,6,9-11)}$. In our previous study, the dietary Thr requirement for juvenile blunt snout has been estimated to be $1.57 \%$ of the diet, corresponding to $4.62 \%$ of dietary protein ${ }^{(5)}$. The same study demonstrated that juvenile blunt snout bream fed with a Thr-deficient diet exhibited poor growth performance and feed utilisation, while these parameters improved in

Abbreviations: 4E-BP, eukaryotic translation initiation factor 4E-binding protein; CAFS, Chinese Academy of Fishery Sciences; DI, distal intestine; FFRC, Freshwater Fisheries Research Center; HSI, hepatosomatic index; HPC, hepatopancreatic protein content; HW, hepatopancreas weight; IGF-I, insulinlike growth factor-I; IPC, intestinal protein content; ISI, intestosomatic index; IW, intestinal weight; MI, mid-intestine; PI, proximal intestine; Thr, threonine; TOR, target of rapamycin.

*Corresponding author: Professor X. Ge, fax +86 51085553304 , email gexp@ffrc.cn

† Present address: Wuxi Fisheries College, Nanjing Agriculture University, Wuxi, Jiangsu 214081, People’s Republic of China; email mike2692011@gmail.com 
response to the graded levels of dietary $\mathrm{Thr}$, which confirmed the essentiality of Thr for this fish ${ }^{(5)}$. A deficiency of dietary Thr also resulted in a reduction in growth performance and feed utilisation efficiency that caused an increase in the oxidation of other essential and non-essential amino acids present at normal levels in a diet of Senegal sole (Solea sene-

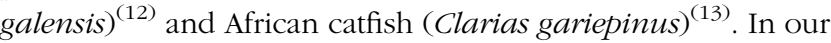
previous study, the deficiency $(0.58 \%)$ and excess $(2.58 \%)$ of dietary Thr led to adverse effects on the growth and immunity of blunt snout bream ${ }^{(6)}$. An anorectic status followed by weight loss also occurred in Indian major $\operatorname{carp}^{(9)}$, grass carp $^{(11)}$, common carp ${ }^{(14)}$, Catla catla $^{(15)}$, Japanese flounder ${ }^{(16)}$ and Indian catfish ${ }^{(17)}$ in response to diets lacking or low in Thr, but containing otherwise adequate levels of all nutrients. An excess level of dietary $\mathrm{Thr}$ in a diet also appeared to have adverse effects on the growth performance of Indian major carps (Labeo rohita ${ }^{(9)}$ and Cirrbinus mrigala ${ }^{(18)}$ ).

Fish growth is dependent on digestion ability, which has been found to correlate with the activity of digestive enzymes ${ }^{(19)}$. The activities of digestive enzymes in fish appear to be strongly correlated with the composition of diet ${ }^{(20,21)}$. Digestion functions in fish rely on the growth and development of digestive organs and activities of digestive enzymes ${ }^{(22,23)}$. Among the essential amino acids, Thr is absorbed in greater proportion by the small intestine in mammals, suggesting that $\mathrm{Thr}$ is involved in intestinal functionality and maintenance ${ }^{(24,25)}$. In piglets, Thr is used to the greatest extent by the portal-drained viscera (including the intestines and pancreas), and $60-80 \%$ of dietary Thr is extracted by the portal-drained viscera in the first pass ${ }^{(26)}$. Meanwhile, intestinal mucins are particularly enriched in Thr (up to $30 \%$ of the amino acid composition) ${ }^{(27)}$. Thr supplementation enhanced the activities of digestive enzymes in Jian carp ${ }^{(28)}$. Nevertheless, there is no report regarding the effect of dietary Thr on the activities of digestive enzymes in blunt snout bream, which needs to be investigated.

Protein synthesis is a key component of the processes involved in growth response ${ }^{(29)}$. It is well known that the target of rapamycin (TOR) signalling pathway plays an important role in regulating protein synthesis in fish ${ }^{(28)}$ and mammals ${ }^{(30)}$. The eukaryotic translation initiation factor 4E-binding protein (4E-BP) family is one of the major downstream targets of TOR protein ${ }^{(31)}$. The increased enzyme activity results from an increased synthesis of enzyme protein ${ }^{(32)}$, which relates to gene expression ${ }^{(33)}$. Gene expression levels of digestive enzymes have been shown to be related to nutritional factors in fish ${ }^{(34,35)}$. The beneficial effect of Thr on the activities of digestive enzymes may be partly related to the synthesis and secretion of enzymes. Nevertheless, there is no report about the relationship between Thr and gene expression levels of digestive enzymes in the hepatopancreas of fish, which is worthy of investigation. Indeed, the present study hypothesised that Thr may play an important role in the growth and development of digestive organs, and that Thr may regulate the mRNA expression levels of digestive enzymes, TOR, 4E-BP2 and $I G F-I$ in the hepatopancreas of blunt snout bream, which may go further to explain the effects of Thr in this fish species. Therefore, the present study was conducted to test the aforementioned hypothesis.

\section{Materials and methods}

\section{Diet preparation and fish rearing}

Diet preparation was carried out as described in our previous study ${ }^{(5)}$. Briefly, five isonitrogenous $(34 \%$ crude protein in DM) and isoenergetic semi-purified diets were formulated to contain graded levels of dietary Thr (Table 1). Thr concentrations in five experimental diets were calculated to be 0.58 (unsupplemented control), $1.08,1.58,2.08$ or $2.58 \%$ of the diet. The diets were supplemented with $0,0.5,1.0,1.5$ or $2.0 \%$ L-crystalline Thr. The diets were made isonitrogenous by adjusting the level of L-glutamic acid. A mixture of L-crystalline amino acids was prepared taking into account the amount of amino acids contributed by fishmeal, casein and gelatin. The mixture was supplemented to simulate the whole-body amino acid pattern of blunt snout bream, except for Thr. The mixture of L-crystalline amino acids was pre-coated with $3 \mathrm{~g}$ cooked carboxymethyl cellulose in water at $60^{\circ} \mathrm{C}$, and then the carboxymethyl cellulose-bound crystalline amino

Table 1. Ingredients and composition of the basal diet*

\begin{tabular}{|c|c|}
\hline \multicolumn{2}{|l|}{ Ingredients (\%) } \\
\hline Fishmeal† & $5 \cdot 00$ \\
\hline Casein $\ddagger$ & $12 \cdot 00$ \\
\hline Gelatin§ & 3.00 \\
\hline Soyabean oill| & $6 \cdot 00$ \\
\hline Soyabean lecithin\| & 1.00 \\
\hline Choline chloride\| & 0.25 \\
\hline Amino acid premix & $15 \cdot 29$ \\
\hline Vitamin $C^{\star *}$ & 0.15 \\
\hline Vitamin and mineral premix $\dagger \dagger$ & $2 \cdot 00$ \\
\hline 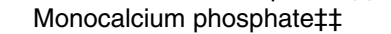 & 2.75 \\
\hline Dextrinł‡ & $35 \cdot 00$ \\
\hline Microcrystalline cellulose $\ddagger \ddagger$ & 8.49 \\
\hline Carboxymethyl cellulose $\ddagger$ & $6 \cdot 32$ \\
\hline Ethoxyquinł‡ & 0.50 \\
\hline L-Glutamic acid & $2 \cdot 25$ \\
\hline \multicolumn{2}{|l|}{ Proximate composition (\% DM)§§ } \\
\hline Crude protein (\%) & 33.96 \\
\hline Crude lipid (\%) & $6 \cdot 85$ \\
\hline Gross energy $(\mathrm{kJ} / \mathrm{g})$ & $16 \cdot 74$ \\
\hline Thr (\%) & 0.61 \\
\hline
\end{tabular}

*Adopted from our previous study ${ }^{(5)}$.

†Crude protein $67.4 \%$ and crude lipid $9.3 \%$, provided by Tongwei Feed Group Company, Limited (origin Copeinca).

$\mp$ Crude protein $90.2 \%$, purchased from Huaan Biological Products Company, Limited.

$\S$ Crude protein $91.3 \%$, purchased from Shanghai Zhan Yun Chemical Company, Limited.

$\|$ Provided by Cargill.

9 Amino acid premix (g/100 g of diet): L-histidine 0.31; L-isoleucine 0.68; L-leucine 0.87; L-lysine 1.09; L-methionine 0.43; L-phenylalanine 0.66; L-threonine 0.71 ; L-valine 0.56; L-aspartic acid 1.46; L-serine 0.55; glycine 1.37; L-alanine 1.25; L-cystine 0.14; L-tyrosine 0.27; L-tryptophan 0.12; L-glutamic acid 1.11; L-proline 0.12 . Amino acids were obtained from Feeer Company, Limited.

** $35 \%$ ascorbic acid equivalent, provided by Tongwei Feed Group Company Limited.

††Premixes of vitamins (IU or $\mathrm{mg} / \mathrm{kg}$ of premix) and minerals ( $\mathrm{g} / \mathrm{kg}$ of premix): vitamin A $900000 \mathrm{IU}$; vitamin D $250000 \mathrm{IU}$; vitamin C $10000 \mathrm{mg}$; vitamin E $4500 \mathrm{mg}$; vitamin $K_{3} 220 \mathrm{mg}$; vitamin $B_{1} 320 \mathrm{mg}$; vitamin $B_{2} 1090 \mathrm{mg}$; vitamin $B_{6}$ $5000 \mathrm{mg}$; vitamin $B_{12} 116 \mathrm{mg}$; biotin $50 \mathrm{mg}$; pantothenate $1000 \mathrm{mg}$; folic acid $165 \mathrm{mg}$; choline $60000 \mathrm{mg}$; inositol $15000 \mathrm{mg}$; niacin acid $2500 \mathrm{mg}$; $\mathrm{CuSO}_{4} .5 \mathrm{H}_{2} \mathrm{O}$ $2.5 \mathrm{~g}: \mathrm{FeSO}_{4} .7 \mathrm{H}_{2} \mathrm{O} 28 \mathrm{~g}: \mathrm{ZnSO}_{4} .7 \mathrm{H}_{2} \mathrm{O} 22 \mathrm{~g}: \mathrm{MnSO}_{4} \cdot 4 \mathrm{H}_{2} \mathrm{O} 9 \mathrm{~g} ; \mathrm{Na}_{2} \mathrm{SeO}_{3} 0.045 \mathrm{~g}$ $\mathrm{KI} 0.026 \mathrm{~g} ; \mathrm{CoCl}_{2} \cdot 6 \mathrm{H}_{2} \mathrm{O} 0.1 \mathrm{~g}$. The premixes were provided by Wuxi Hanove Animal Health Products Company Limited.

\#‡Provided by Guangzhou Hinter Biotechnology Company, Limited.

$\S \S$ Values for the proximate composition of the test diets are means of triplicate analyses. 
acid mixture was blended with the other thoroughly mixed dry ingredients followed by the addition of oils and water, until well homogenised $^{(36,37)}$. Pellets $(1.5$ and $2.0 \mathrm{~mm}$ in diameter) were produced using laboratory twin-screw extruder (Science and Technology Industrial Factory of South China University of Technology), air-dried to approximately $10 \%$ moisture, sealed in vacuum-packed bags, and stored frozen $\left(-15^{\circ} \mathrm{C}\right)$ before use in the feeding trial. Table 2 shows the amino acid composition of ingredients ( $\mathrm{g} / 100 \mathrm{~g}$ DM). The composition of amino acids in the experimental diets (Table 3, g/100 g of diet) was analysed according to the method described by Ren et al. ${ }^{(7)}$.

The use of the experimental fish was according to the scientific research protocols of the Chinese Academy of Fishery Sciences (CAFS) and the Ministry of Agriculture, PR China, and complied with all relevant local and/or international animal welfare laws, guidelines and policies ${ }^{(38)}$. Fish rearing was conducted as described in our previous study ${ }^{(5)}$. Briefly, juvenile blunt snout bream were obtained from Freshwater Fisheries Research Center (FFRC) and acclimatised with experimental facilities for 2 weeks. During the acclimatisation period, fish were fed with the basal diet (0.58\% Thr) up to satiation. At the start of the feeding trial, similar size of fish (initial weight 3.01 (SEM 0.01) g) was selected and restocked at a stocking density of thirty fish per tank. Overall, three tanks (300 litres/tank) were randomly arranged and assigned to each experimental diet. Fish were hand-fed with their respective diet four times daily (at 08.00, 11.00, 14.00 and 17.00 hours) to apparent satiation on the basis of visual observation. The uneaten diet was siphoned from each tank before feeding on daily basis. The following parameters were maintained during the experimental period: water temperature, $26-28^{\circ} \mathrm{C} ; \quad \mathrm{pH}, \quad 7 \cdot 0-7 \cdot 5 ; \quad \mathrm{NH}_{3} \quad \mathrm{~N}, \quad<0.05 \mathrm{mg} / \mathrm{l} ;$ dissolved oxygen, $\geq 6.0 \mathrm{mg} / 1$; photoperiod, natural (light-dark cycle).

\section{Sample collection}

At the end of the 9-week feeding trial, fish were starved for $24 \mathrm{~h}$ to evacuate the contents of the alimentary tract before the sampling period. Fish were sampled (from each tank) and anaesthetised with $100 \mathrm{mg} / \mathrm{l}$ of tricaine methanesulfonate (MS-222). For each group, fifteen fish (five fish per tank) were weighed and dissected, and samples of their hepatopancreas and intestine were removed and weighed to calculate hepatopancreas weight (HW), hepatosomatic index (HSI), intestinal weight (IW) and intestosomatic index (ISI). Among the fifteen fish, nine were randomly selected and their hepatopancreas and intestine were used to measure the hepatopancreatic protein content (HPC) and intestinal protein content (IPC). Meanwhile, from same individual samples (nine fish), the hepatopancreas and intestinal segments (divided into the proximal intestine (PI), mid-intestine (MI) and distal intestine (DI)) were used to assay the activities of digestive enzymes. Another three fish from each tank (nine per group) were dissected, and samples of their hepatopancreas were quickly removed for gene expression assay. All samples were frozen in liquid $\mathrm{N}_{2}$ and then stored at $-80^{\circ} \mathrm{C}$ for the subsequent analysis of the following: activities of digestive enzymes (chymotrypsin, trypsin, amylase and lipase) in the hepatopancreas and three intestinal segments; gene expression levels of chymotrypsin, trypsin, amylase, lipase, TOR, $4 E-B P 2$ and $I G F-I$ in the hepatopancreas.

\section{Enzyme activity assay}

The hepatopancreas and intestinal samples were homogenised in ten volumes (w/v) of ice-cold physiological saline and centrifuged at $6000 \mathrm{~g}$ for $20 \mathrm{~min}$ at $4^{\circ} \mathrm{C}$, and the supernatant was conserved at $-80^{\circ} \mathrm{C}$ for the analysis of enzyme activities. The IPC and HPC were measured using the method of Bradford ${ }^{(39)}$

Table 2. Amino acid composition of ingredients $(\mathrm{g} / 100 \mathrm{~g} \mathrm{DM})^{\star}$

\begin{tabular}{|c|c|c|c|c|c|c|}
\hline \multirow[b]{2}{*}{ Amino acids } & \multicolumn{4}{|c|}{ Amount in } & \multirow[b]{2}{*}{ Total } & \multirow[b]{2}{*}{ WBP (34 \%) } \\
\hline & $12 \mathrm{~g}$ casein & $3 \mathrm{~g}$ gelatin & $5 \mathrm{~g}$ fishmeal & CAAP & & \\
\hline \multicolumn{7}{|l|}{ Essential } \\
\hline Arg & 0.34 & 0.19 & 0.18 & 1.30 & 2.01 & $2 \cdot 01$ \\
\hline His & 0.27 & 0.01 & 0.11 & 0.38 & 0.76 & 0.76 \\
\hline Ile & 0.50 & 0.04 & 0.14 & 0.81 & 1.49 & 1.49 \\
\hline Leu & 0.97 & 0.07 & 0.23 & 1.13 & $2 \cdot 40$ & $2 \cdot 40$ \\
\hline Lys & 0.80 & 0.09 & 0.23 & 1.32 & $2 \cdot 43$ & 2.43 \\
\hline Met & 0.29 & 0.02 & 0.09 & 0.50 & 0.90 & 0.90 \\
\hline Phe & 0.50 & 0.05 & 0.14 & 0.79 & 1.47 & 1.47 \\
\hline Thr & 0.44 & 0.04 & 0.11 & 0.00 & 0.58 & 1.41 \\
\hline Val & 0.62 & 0.06 & 0.16 & 0.73 & 1.57 & 1.57 \\
\hline \multicolumn{7}{|l|}{ Non-essential } \\
\hline Asp & 0.77 & $0 \cdot 12$ & 0.27 & 1.68 & $2 \cdot 84$ & $2 \cdot 84$ \\
\hline Ser & 0.56 & 0.07 & 0.12 & 0.70 & 1.45 & 1.45 \\
\hline Gly & 0.19 & 0.55 & 0.19 & 1.56 & $2 \cdot 50$ & $2 \cdot 50$ \\
\hline Ala & 0.34 & 0.22 & 0.20 & 1.39 & $2 \cdot 14$ & $2 \cdot 14$ \\
\hline Cys & 0.03 & 0.00 & 0.02 & 0.15 & $0 \cdot 19$ & $0 \cdot 19$ \\
\hline Tyr & 0.55 & 0.02 & $0 \cdot 10$ & 0.41 & 1.07 & 1.07 \\
\hline Glu & $2 \cdot 23$ & 0.26 & 0.42 & 1.73 & $4 \cdot 64$ & 4.64 \\
\hline Pro & 0.95 & 0.31 & $0 \cdot 10$ & 0.55 & 1.92 & 1.92 \\
\hline
\end{tabular}

CAAP, crystalline amino acid premix; WBP, whole-body protein.

${ }^{*}$ Calculated according to the method described by Habte-Tsion et al. ${ }^{(5)}$ and Ren et al. ${ }^{(7)}$. Tryptophan could not be measured because of its degradation during acid hydrolysis. 
Table 3. Analysis of amino acid composition in the experimental diets $(\mathrm{g} / 100 \mathrm{~g}$ of diet)*

\begin{tabular}{lccccc}
\hline & \multicolumn{5}{c}{ Diet no. } \\
\cline { 2 - 6 } Amino acids & 1 & 2 & 3 & 4 & 5 \\
\hline Essential & & & & & \\
Arg & 1.94 & 1.97 & 1.95 & 1.87 & 1.87 \\
His & 0.71 & 0.68 & 0.68 & 0.68 & 0.66 \\
Ile & 1.55 & 1.56 & 1.56 & 1.46 & 1.48 \\
Leu & 2.37 & 2.32 & 2.35 & 2.23 & 2.18 \\
Lys & 2.23 & 2.29 & 2.26 & 2.17 & 2.18 \\
Met & 0.79 & 0.80 & 0.79 & 0.76 & 0.77 \\
Phe & 1.50 & 1.45 & 1.44 & 1.45 & 1.40 \\
Thr & 0.61 & 1.06 & 1.49 & 2.04 & 2.49 \\
Val & 1.61 & 1.66 & 1.71 & 1.63 & 1.52 \\
Non-essential & & & & & \\
Asp & 2.85 & 2.83 & 2.87 & 2.83 & 2.94 \\
Ser & 1.33 & 1.34 & 1.33 & 1.26 & 1.28 \\
Gly & 1.97 & 2.46 & 2.40 & 2.46 & 2.40 \\
Ala & 0.83 & 0.82 & 0.83 & 0.80 & 1.63 \\
Cys & 0.09 & 0.09 & 0.10 & 0.09 & 0.09 \\
Tyr & 1.19 & 0.88 & 0.86 & 0.81 & 0.83 \\
Glu & 7.16 & 6.23 & 6.20 & 5.34 & 4.94 \\
Pro & 2.26 & 2.23 & 2.16 & 2.01 & 2.09 \\
\hline
\end{tabular}

*Adopted from our previous study ${ }^{(5)}$, and data are means of three replicates. Tryptophan could not be measured because of its degradation during acid hydrolysis.

Trypsin and chymotrypsin activities were determined by the method described by Hummel ${ }^{(40)}$. Lipase and amylase activities were assayed as described by Furne et al. ${ }^{(41)}$

\section{Real-time PCR analysis}

Real-time PCR analysis was carried out according to our previous studies ${ }^{(5,6)}$. Briefly, total RNA was extracted from the hepatopancreas of juvenile blunt snout bream using an RNAiso Plus Kit (Takara). Agarose gel electrophoresis at 1\% and spectrophotometric analysis (A260:280 nm ratio) were used to assess RNA quality and quantity. Subsequently, complementary DNA (cDNA) was synthesised using a PrimeScript ${ }^{\mathrm{TM}}$ RT reagent kit (Takara), according to the manufacturer's instructions. Briefly, oligo dT primers $(50 \mu \mathrm{M})$ were used to reverse transcribe respective RNA in the presence of PrimeScript $^{\mathrm{TM}}$ RT enzyme mix I, $5 \times$ PrimeScript $^{\mathrm{TM}}$ buffer, and RNase-free distilled water at $37^{\circ} \mathrm{C}$ for $15 \mathrm{~min}$ followed by inactivation at $85^{\circ} \mathrm{C}$ for $5 \mathrm{~s}$. Specific primers for most of the target genes were designed according to the partial cDNA sequences of the target genes using the $M$. amblycephala transcriptome analysis ${ }^{(5,6,42)}$, and primers for lipase and $\beta$-actin were designed using the published sequences of blunt snout bream (GeneBank no. KF114279.1 and AY170122.2, respectively; Table 4). All primers were synthesised by Shanghai Biocolor, BioScience \& Technology Company.

Real-time PCR was used to determine mRNA levels using a PrimerScript ${ }^{\mathrm{TM}}$ Reagent Kit (Takara). Real-time PCR for the target genes were performed according to standard protocols. Briefly, cDNA $(2 \cdot 0 \mu \mathrm{l})$ was reacted with $10 \cdot 0 \mu \mathrm{l} \mathrm{SYBR}{ }^{\circledR}$ Premix Ex Taq II $(2 \times), 0 \cdot 8 \mu \mathrm{l}$ forward primer $(10 \mu \mathrm{M}), 0 \cdot 8 \mu \mathrm{l}$ reverse primer $(10 \mu \mathrm{M}), 0.4 \mu \mathrm{ROX}^{\mathrm{TM}}$ reference dye or dye II $(50 \times)$, and $6.0 \mu \mathrm{l}$ RNase-free distilled water in a final reaction volume of $20 \mu \mathrm{l}$. The real-time PCR was carried out in a 7500
Real-Time PCR System (Applied Biosystems). The thermocycling conditions for the target genes were as follows: initial denaturation step at $95^{\circ} \mathrm{C}$ for $30 \mathrm{~s}$, followed by forty cycles at $95^{\circ} \mathrm{C}$ for $5 \mathrm{~s}, 60^{\circ} \mathrm{C}$ for $34 \mathrm{~s}$ and $95^{\circ} \mathrm{C}$ for $30 \mathrm{~s}, 95^{\circ} \mathrm{C}$ for $3 \mathrm{~s}$, $60^{\circ} \mathrm{C}$ for $30 \mathrm{~s}$, respectively. The melting curve analysis was performed over a range of $50-95^{\circ} \mathrm{C}$ to verify that a single PCR product was generated. The concentration of the target genes was based on the threshold cycle number $\left(C_{\mathrm{T}}\right)$, and $C_{\mathrm{T}}$ for each sample was determined using 7500 Software version 2.0.4 (Applied Biosystems). The expression levels of the target genes were normalised to those of a housekeeping gene $(\beta$-actin) of blunt snout bream. The expression results were analysed using the $2^{-\Delta \Delta C_{\mathrm{T}}}$ method after verifying that the primers were amplified with an efficiency of approximately $100 \%{ }^{(43)}$. Besides, cDNA concentration in each sample was determined according to gene-specific standard curves. Standard curves were generated for both target and endogenous control genes based on 10-fold serial dilutions. All standard curves exhibited correlation coefficients $>0.99$.

\section{Calculations and statistical analysis}

The growth and development of digestive organs in juvenile blunt snout bream fed with the graded levels of dietary Thr for 9 weeks were calculated using the following formulas:

$$
\text { HSI }=(\text { wet HW }(\mathrm{g}) / \text { wet body weight }(\mathrm{g})) \times 100,
$$

$\mathrm{HPC}=($ hepatopancreatic protein $(\mathrm{g}) /$ wet HW $(\mathrm{g})) \times 100$,

$$
\begin{aligned}
\mathrm{ISI} & =(\text { wet IW }(\mathrm{g}) / \text { wet body weight }(\mathrm{g})) \times 100, \\
\mathrm{IPC} & =(\text { intestinal protein }(\mathrm{g}) / \text { wet IW }(\mathrm{g})) \times 100 .
\end{aligned}
$$

\begin{tabular}{|c|c|c|}
\hline Target genes & Primer sequence & $\begin{array}{l}\text { Amplicon } \\
\text { length (bp) }\end{array}$ \\
\hline \multicolumn{3}{|l|}{ Chymotrypsin } \\
\hline Forward & 5'-CAGCGAGACACACAGGAGAC-3' & 20 \\
\hline Reverse & 5'-CAGCTACACCATCAACAATGAC-3' & 22 \\
\hline \multicolumn{3}{|c|}{ e } \\
\hline Forward & 5'-CTGGGTTGTTTCTGCTGCT-3' & 19 \\
\hline Reverse & 5'-GAGGTGATGTACTGCTCAGAAC-3' & 22 \\
\hline \multicolumn{3}{|l|}{ Amylase } \\
\hline Forward & 5'-CACTCAAGCTGTGGATCATATT-3' & 22 \\
\hline Reverse & 5-GGTGTAGCATTTGCCATCAT-3 & 20 \\
\hline \multicolumn{3}{|c|}{ 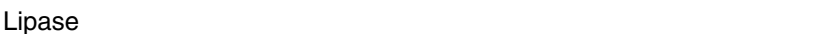 } \\
\hline Forward & 5'-GTTTCTGGATTTGGGTCG-3' & 18 \\
\hline Reverse & 5'-TCTGATGGGATCTGGCAC-3' & 18 \\
\hline \multicolumn{3}{|c|}{ e } \\
\hline Forward & 5'-TTTACACGAGCAAGTCTACGGA-3' & 22 \\
\hline Reverse & 5'-CTTCATCTTGGCTCAGCTCTCT-3' & 22 \\
\hline \multicolumn{3}{|l|}{$4 E-B P 2$} \\
\hline Forward & 5'-ATGTCGTCCAGTCGTCAGTTT-3' & 21 \\
\hline Reverse & 5'-AGGAGTGGTGCAATAGTCGTG-3' & 21 \\
\hline \multicolumn{3}{|c|}{ 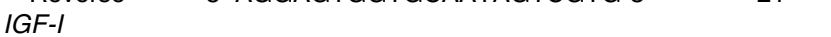 } \\
\hline Forward & 5'-CTCACTGGTGCTGTTCGTCCTC-3' & 22 \\
\hline Reverse & 5'-TGAAAGCAGCATTCGTCCACA-3' & 21 \\
\hline \multicolumn{3}{|l|}{$\beta$-Actin } \\
\hline Forward & 5'-TCGTCCACCGCAAATGCTTCTA-3' & 22 \\
\hline Reverse & 5'-CCGTCACCTTCACCGTTCCAGT-3' & 22 \\
\hline
\end{tabular}

Table 4. Real-time PCR primer sequences

TOR, target of rapamycin; 4E-BP2, eukaryotic translation initiation factor $4 \mathrm{E}$-binding protein 2 ; IGF-I, insulin-like growth factor-I. 
Statistical analysis was performed using SPSS version 19 (SPSS, Inc.). All data were subjected to one-way ANOVA followed by least significant difference multiple comparisons. Significant differences among group means as well as between intestinal segment (PI, MI and DI) means were further compared using Duncan's multiple range tests. $P<0.05$ was considered statistically significant. Results are expressed as means with their standard errors. The relationship between dietary Thr and the growth and development of digestive organs and activities of digestive enzymes, as well as gene expression levels of digestive enzymes, TOR, $4 E-B P 2$ and $I G F-I$ in the hepatopancreas, respectively, were subjected to a second-degree polynomial regression analysis ${ }^{(44)}$ and the quadratic regression model using SPSS version 19.

\section{Results}

\section{Growth and development of digestive organs}

Table 5 shows the growth and development of digestive organs in juvenile blunt snout bream fed with the graded levels of dietary Thr for 9 weeks. The HW, HSI, HPC, IW, ISI and IPC were significantly $(P<0.05)$ influenced by dietary Thr levels. The HW and IW increased as dietary Thr levels increased up to $1.58 \%(P<0.05)$, remained plateau up to $2.08 \%$ and then declined. The highest HSI was found in the group fed with $1.58 \%$ dietary $\operatorname{Thr}(P<0.05)$. The HPC increased as dietary $\mathrm{Thr}$ levels increased, and a maximum value was found in the group fed with $1.58 \%$ dietary Thr followed by those fed with $1.08 \%$ dietary $\mathrm{Thr}(P<0.05)$. The ISI increased with increasing dietary Thr levels up to $1.58 \%$ and thereafter declined $(P<0 \cdot 05)$. The highest IPC was obtained in the group fed with $1.58 \%$ dietary $\mathrm{Thr}$, while the lowest value was obtained in that fed with the basal diet $(P<0.05)$. Significant differences in the IPC were found between 1.58 and $2.08 \%$ dietary Thr, and between 2.08 and $2.58 \%$ dietary Thr $(P<0.05)$. The HW, HSI, HPC, IW, ISI and IPC of the group fed with the basal diet $(0.58 \% \mathrm{Thr})$ and the $2.58 \%$ Thr diet were significantly $(P<0.05)$ lower than those of the group fed with the $1.58 \%$ Thr diet. The HW, HSI, HPC, IW, ISI and IPC quadratically responded to the dietary Thr levels. Based on the quadratic equations in Table 5 , the optimum Thr levels for each parameter were 1.87, 1.66, 1.59, 1.68, 1.61 and $1.68 \%$, respectively.

\section{Activities of digestive enzymes in the hepatopancreas}

Table 6 shows the activities of digestive enzymes in the hepatopancreas of juvenile blunt snout bream fed with the graded levels of dietary Thr for 9 weeks. The highest chymotrypsin activity was found in the group fed with 1.58 and $2.08 \%$ dietary Thr $(P<0.05)$. Trypsin activity in the hepatopancreas increased as dietary Thr levels increased up to $1.58 \%$, remained plateau up to $2.08 \%$ and thereafter declined $(P<0.05)$. Amylase and lipase activities in the hepatopancreas increased with increasing dietary Thr levels, and the highest activities were observed in fish fed with $1.58 \%$ dietary $\mathrm{Thr}$ $(P<0.05)$. The activities of digestive enzymes in the group fed with 0.58 and $2.58 \%$ dietary Thr were significantly lower than those in the group fed with $1.58 \%$ dietary Thr $(P<0.05)$. Digestive enzyme activities in the hepatopancreas quadratically responded to the dietary Thr levels. Based on the quadratic equations in Table 6, the optimum Thr levels for chymotrypsin, trypsin, amylase and lipase, were 1.72 , $1.72,1.77$ and $1.66 \%$, respectively.

Table 5. Growth and development of digestive organs in juvenile blunt snout bream fed with the graded levels of dietary Thr for 9 weeks ${ }^{\star}$ (Mean values with their standard errors)

\begin{tabular}{|c|c|c|c|c|c|c|c|c|c|c|}
\hline \multirow[b]{3}{*}{ Parameters } & \multicolumn{10}{|c|}{ Dietary Thr levels (\%) } \\
\hline & \multicolumn{2}{|c|}{0.58} & \multicolumn{2}{|c|}{1.08} & \multicolumn{2}{|c|}{1.58} & \multicolumn{2}{|c|}{$2 \cdot 08$} & \multicolumn{2}{|c|}{$2 \cdot 58$} \\
\hline & Mean & SEM & Mean & SEM & Mean & SEM & Mean & SEM & Mean & SEM \\
\hline \multicolumn{11}{|l|}{ Hepatopancreas } \\
\hline$H W^{*}(g)$ & $0.51^{a}$ & 0.01 & $0.56^{a, b}$ & 0.00 & $0.67^{d}$ & 0.02 & $0.64^{c, d}$ & 0.00 & 0.60 & $0.03^{b c}$ \\
\hline $\mathrm{HSI}^{*}(\%)$ & $3 \cdot 32^{a}$ & 0.21 & $3.49^{a}$ & 0.08 & $4.98^{b}$ & 0.07 & $3.95^{\mathrm{a}}$ & 0.25 & $3.53^{a}$ & 0.36 \\
\hline $\mathrm{HPC}+(\%)$ & $62^{a}$ & 6 & $73^{\mathrm{b}, \mathrm{c}}$ & 2 & $81^{c}$ & 1 & $70^{\mathrm{a}, \mathrm{b}}$ & 2 & $64^{a, b}$ & 3 \\
\hline \multicolumn{11}{|l|}{ Intestine } \\
\hline $\mathrm{IW}^{*}(\mathrm{~g})$ & $0.50^{a}$ & 0.03 & $0.63^{b, c}$ & 0.06 & $0.71^{c}$ & 0.04 & $0.69^{c}$ & 0.03 & $0.56^{\mathrm{a}, \mathrm{b}}$ & 0.02 \\
\hline $\mathrm{ISI}^{*}(\%)$ & $3 \cdot 17^{\mathrm{a}}$ & 0.03 & $3 \cdot 99^{a, b}$ & 0.34 & $5 \cdot 26^{c}$ & 0.36 & $4 \cdot 26^{\mathrm{b}}$ & 0.36 & $3 \cdot 25^{\mathrm{a}}$ & 0.16 \\
\hline $\mathrm{IPC}+(\%)$ & $46^{a}$ & 2 & $65^{c}$ & 2 & $73^{d}$ & 1 & $66^{c}$ & 2 & $56^{\mathrm{b}}$ & 2 \\
\hline \multicolumn{5}{|l|}{ Regression } & \multicolumn{4}{|c|}{$R^{2}$} & \multicolumn{2}{|c|}{$P$} \\
\hline \multirow{6}{*}{\multicolumn{5}{|c|}{$\begin{array}{l}Y_{\mathrm{HW}}=-0.089 x^{2}+0.333 x+0.337 \\
Y_{\mathrm{HSI}}=-1.062 x^{2}+3.534 x+1.454 \\
Y_{\mathrm{HPC}}=-15 \cdot 15 x^{2}+48.14 x+39.34 \\
Y_{\mathrm{IW}}=-0.178 x^{2}+0.599 x+0.206 \\
Y_{\mathrm{ISI}}=-1.696 x^{2}+5.447 x+0.460 \\
Y_{\mathrm{IPC}}=-20.83 x^{2}+69.95 x+13.01\end{array}$}} & & \multicolumn{2}{|c|}{$<0.001$} \\
\hline & & & & & \multicolumn{4}{|c|}{0.591} & \multicolumn{2}{|c|}{$<0.05$} \\
\hline & & & & & \multicolumn{4}{|c|}{0.878} & \multicolumn{2}{|c|}{$<0.01$} \\
\hline & & & & & \multicolumn{4}{|c|}{0.990} & \multicolumn{2}{|c|}{$<0.01$} \\
\hline & & & & & \multicolumn{4}{|c|}{0.869} & \multirow{2}{*}{\multicolumn{2}{|c|}{$\begin{array}{l}<0.05 \\
<0.001\end{array}$}} \\
\hline & & & & & \multicolumn{4}{|c|}{0.975} & & \\
\hline
\end{tabular}

HW, hepatopancreas weight; HSI, hepatosomatic index; HPC, hepatopancreatic protein content; IW, intestinal weight; ISI, intestosomatic index; IPC, intestinal protein content. a,b,c,d Mean values within a row with unlike superscript letters were significantly different $(P<0.05)$.

${ }^{*} n 15$.

† $n 9$. 
Table 6. Activities of digestive enzymes in the hepatopancreas of juvenile blunt snout bream fed with the graded levels of dietary threonine (Thr) for 9 weeks

(Mean values with their standard errors; $n$ 9)

\begin{tabular}{|c|c|c|c|c|c|c|c|c|c|c|}
\hline \multirow[b]{3}{*}{ Enzymes (U/g tissue) } & \multicolumn{10}{|c|}{ Dietary Thr levels (\%) } \\
\hline & \multicolumn{2}{|c|}{0.58} & \multicolumn{2}{|c|}{1.08} & \multicolumn{2}{|c|}{$1 \cdot 58$} & \multicolumn{2}{|c|}{2.08} & \multicolumn{2}{|c|}{$2 \cdot 58$} \\
\hline & Mean & SEM & Mean & SEM & Mean & SEM & Mean & SEM & Mean & SEM \\
\hline Chymotrypsin & $3 \cdot 02^{\mathrm{a}}$ & 0.34 & $3 \cdot 68^{b}$ & 0.16 & $4 \cdot 77^{c}$ & 0.06 & $4 \cdot 39^{c}$ & 0.12 & $3 \cdot 54^{\mathrm{a}, \mathrm{b}}$ & 0.16 \\
\hline Trypsin & $1.94^{\mathrm{a}}$ & 0.06 & $2 \cdot 11^{b}$ & 0.05 & $2 \cdot 33^{c}$ & 0.02 & $2 \cdot 22^{b, c}$ & 0.04 & $2 \cdot 08^{\mathrm{a}, \mathrm{b}}$ & 0.03 \\
\hline Amylase & $1668^{a}$ & 15 & $1759^{b}$ & 15 & $1866^{c}$ & 13 & $1808^{b}$ & 19 & $1761^{b}$ & 27 \\
\hline Lipase & $305^{a}$ & 16 & $405^{\mathrm{b}}$ & 19 & $562^{d}$ & 13 & $509^{c}$ & 19 & $340^{a}$ & 12 \\
\hline \multicolumn{5}{|l|}{ Regression } & \multicolumn{4}{|c|}{$R^{2}$} & \multicolumn{2}{|c|}{$P$} \\
\hline \multirow{4}{*}{\multicolumn{5}{|c|}{$\begin{array}{l}Y_{\text {chymotrypsin }}=-1 \cdot 283 x^{2}+4.404 x+0.767 \\
Y_{\text {trypsin }}=-0.274 x^{2}+0.944 x+1.467 \\
Y_{\text {amylase }}=-126 \cdot 1 x^{2}+445 \cdot 4 x+1446 \\
Y_{\text {lipase }}=-213.9 x^{2}+710 \cdot 2 x-56.89\end{array}$}} & \multicolumn{4}{|c|}{0.894} & \multicolumn{2}{|c|}{$<0.001$} \\
\hline & & & & & \multicolumn{4}{|c|}{0.917} & \multicolumn{2}{|c|}{$<0.001$} \\
\hline & & & & & \multicolumn{4}{|c|}{0.914} & \multicolumn{2}{|c|}{$<0.001$} \\
\hline & & & & & \multicolumn{4}{|c|}{0.898} & \multicolumn{2}{|c|}{$<0.001$} \\
\hline
\end{tabular}

\section{Activities of digestive enzymes in intestinal segments}

Digestive enzyme activities in the PI, MI and DI of blunt snout bream fed with the graded levels of dietary Thr for 9 weeks are presented in Table 7 . The activities of chymotrypsin in the PI, MI and DI first increased up to $1.58 \%$ dietary Thr and thereafter declined $(P<0 \cdot 05)$. Thr supplementation significantly increased chymotrypsin activities in the PI, MI and DI, compared with the unsupplemented diet $(P<0 \cdot 05)$. Trypsin activities in the PI, MI and DI increased with increasing dietary Thr levels up to $1.58 \%$ and thereafter decreased $(P<0.05)$. Trypsin activities in the PI, MI and DI significantly responded to the addition of $\mathrm{Thr}$ in comparison with the basal diet $(P<0.05)$. Amylase activities in the PI, MI and DI increased as dietary Thr levels increased, and maximum activities were observed in the group fed the diet containing $1.58 \%$ $\operatorname{Thr}(P<0.05)$. The highest lipase activities in the PI, MI and DI were found in the group fed with $1.58 \%$ dietary $\mathrm{Thr}(P<0.05)$. Significantly lower digestive enzyme activities in the PI, MI and DI were found in the group fed with 0.58 and $2.58 \%$ dietary $\mathrm{Thr}$ compared with those in the group fed with $1.58 \%$ dietary Thr $(P<0.05)$. Significantly different levels of chymotrypsin, trypsin, amylase and lipase activities were found between the three intestinal segments (PI, MI and DI), with the highest activities in the PI followed by the MI $(P<0 \cdot 01)$. Digestive enzyme activities in the three intestinal segments quadratically responded to the graded levels of dietary Thr. Based on the quadratic equations in Table 7 , the optimum Thr levels were 1.73, 1.63 and $1.68 \%$ for chymotrypsin in the PI, MI and DI, respectively; $1.78,1.67$ and $1.66 \%$ for trypsin in the PI, MI and DI, respectively; $1.67,1.62$ and $1.61 \%$ for amylase in the PI, MI and DI, respectively; 1.62 , 1.61 and $1.62 \%$ for lipase in the PI, MI and DI, respectively.

\section{Gene expression of digestive enzymes in the} hepatopancreas

Fig. 1 shows the gene expression levels of digestive enzymes, chymotrypsin, trypsin, amylase and lipase in the hepatopancreas of juvenile blunt snout bream fed with the graded levels of dietary Thr for 9 weeks. The relative mRNA expression levels of chymotrypsin increased as dietary $\mathrm{Thr}$ levels increased up to $1.58 \%$ and thereafter fluctuated (Fig. 1(A)). The relative mRNA expression levels of trypsin (Fig. 1(B)) and lipase (Fig. 1(D)) increased with increasing dietary Thr levels up to $1.58 \%$ and remained plateau thereafter. The highest relative mRNA expression level of amylase (Fig. 1(C)) was found in the group fed with $1.58 \%$ dietary Thr $(P<0.05)$. The relative gene expression levels of digestive enzymes in the hepatopancreas quadratically responded to the dietary Thr levels ( $Y_{\text {chemotrypsin }}=-0 \cdot 701 x^{2}+2 \cdot 870$ $x-0.918, \quad R^{2} 0.479, \quad P=0.079 ; \quad Y_{\text {trypsin }}=-1.02 x^{2}+3.667$ $x-0.959, R^{2} 0.891, P=0.015 ; \quad Y_{\text {amylase }}=-1.009 x^{2}+3.276$ $x-1.288, \quad R^{2} 0.432, \quad P=0.098 ; \quad Y_{\text {lipase }}=-0.731 x^{2}+2.650$ $\left.x-0.365, R^{2} 0.840, \quad P=0.030\right)$. Based on the quadratic equations, the optimum Thr levels for the relative mRNA expression levels of chymotrypsin, trypsin, amylase and lipase were $2.05,1.80,1.62$ and $1.81 \%$, respectively.

\section{Gene expression of target of rapamycin, eukaryotic translation initiation factor $4 E$-binding protein 2 and insulin-like growth factor-I in the hepatopancreas}

The relative mRNA expression levels of TOR, $4 E-B P 2$ and $I G F-I$ in the hepatopancreas of blunt snout bream fed with the graded levels of dietary Thr are shown in Fig. 2. The relative mRNA expression levels of TOR (Fig. 2(A)) and IGF-I (Fig. 2(C)) first increased up to $1.58 \%$ dietary Thr, and the values were significantly decreased thereafter $(P<0.05)$. In contrast, the relative mRNA expression levels of $4 E-B P 2$ (Fig. 2(B)) gradually decreased $(P<0 \cdot 10)$ as dietary $\mathrm{Thr}$ levels increased up to $1.58 \%$ and significantly increased thereafter $(P<0.05)$. The relative mRNA expression levels of $T O R, \quad 4 E-B P 2$ and $I G F-I$ in the hepatopancreas quadratically responded to the dietary $\mathrm{Thr}$ levels $\left(Y_{\mathrm{TOR}}=-1.355 x^{2}+4.501 x-1.905, \quad R^{2} \quad 0.672, \quad P=0.005 ;\right.$ $Y_{4 \mathrm{E}-\mathrm{BP} 2}=1.079 x^{2}-2 \cdot 733 x+2 \cdot 485, \quad R^{2} \quad 0.895, \quad P=0.015$; 
Table 7. Activities of digestive enzymes in the proximal intestine (PI), mid-intestine (MI) and distal intestine (DI) of juvenile blunt snout bream fed with the graded levels of dietary threonine (Thr) for 9 weeks

(Mean values with their standard errors; $n$ 9)

\begin{tabular}{|c|c|c|c|c|c|c|c|c|c|c|}
\hline \multirow[b]{3}{*}{ Enzymes (U/g tissue) } & \multicolumn{10}{|c|}{ Dietary Thr levels (\%) } \\
\hline & \multicolumn{2}{|c|}{0.58} & \multicolumn{2}{|c|}{1.08} & \multicolumn{2}{|c|}{1.58} & \multicolumn{2}{|c|}{$2 \cdot 08$} & \multicolumn{2}{|c|}{2.58} \\
\hline & Mean & SEM & Mean & SEM & Mean & SEM & Mean & SEM & Mean & SEM \\
\hline \multicolumn{11}{|l|}{ Chymotrypsin } \\
\hline PI & $2 \cdot 32^{a, C}$ & 0.05 & $3 \cdot 22^{b, c}$ & $0 \cdot 10$ & $4 \cdot 30^{\mathrm{d}, \mathrm{C}}$ & 0.13 & $3 \cdot 52^{\mathrm{c}, \mathrm{C}}$ & 0.10 & $3 \cdot 12^{\mathrm{b}, \mathrm{C}}$ & 0.05 \\
\hline $\mathrm{MI}$ & $1 \cdot 37^{\mathrm{a}, \mathrm{B}}$ & 0.02 & $2 \cdot 31^{\mathrm{c}, \mathrm{B}}$ & 0.11 & $3 \cdot 25^{\mathrm{d}, \mathrm{B}}$ & 0.06 & $2 \cdot 28^{\mathrm{c}, \mathrm{B}}$ & 0.11 & $1 \cdot 73^{\mathrm{b}, \mathrm{B}}$ & 0.05 \\
\hline DI & $0.55^{\mathrm{a}, \mathrm{A}}$ & 0.07 & $0.87^{\mathrm{b}, \mathrm{A}}$ & 0.08 & $1.54^{\mathrm{c}, \mathrm{A}}$ & 0.02 & $0.98^{\mathrm{b}, \mathrm{A}}$ & 0.11 & $0.81^{\mathrm{b}, \mathrm{A}}$ & 0.04 \\
\hline \multicolumn{11}{|l|}{ Trypsin } \\
\hline $\mathrm{PI}$ & $2.09^{\mathrm{a}, \mathrm{C}}$ & 0.07 & $2 \cdot 39^{b, c}$ & 0.09 & $3.05^{\mathrm{d}, \mathrm{C}}$ & 0.08 & $2 \cdot 67^{\mathrm{c}, \mathrm{C}}$ & 0.05 & $2 \cdot 50^{\mathrm{b}, \mathrm{c}, \mathrm{C}}$ & 0.06 \\
\hline MI & $1 \cdot 22^{\mathrm{a}, \mathrm{B}}$ & 0.04 & $1 \cdot 70^{\mathrm{c}, \mathrm{B}}$ & 0.05 & $2 \cdot 02^{\mathrm{d}, \mathrm{B}}$ & 0.05 & $1 \cdot 66^{\mathrm{b}, \mathrm{c}, \mathrm{B}}$ & 0.09 & $1 \cdot 50^{\mathrm{b}, \mathrm{B}}$ & 0.08 \\
\hline DI & $0.02^{a, A}$ & 0.01 & $0.08^{\mathrm{c}, \mathrm{A}}$ & 0.01 & $0 \cdot 12^{\mathrm{d}, \mathrm{A}}$ & 0.01 & $0.07^{\mathrm{c}, \mathrm{A}}$ & 0.00 & $0.05^{\mathrm{b}, \mathrm{A}}$ & 0.00 \\
\hline \multicolumn{11}{|l|}{ Amylase } \\
\hline $\mathrm{Pl}$ & $1015^{\mathrm{a}, \mathrm{C}}$ & 32 & $1142^{b, C}$ & 21 & $1367^{c, C}$ & 21 & $1175^{\mathrm{b}, \mathrm{C}}$ & 33 & $1102^{b, C}$ & 27 \\
\hline MI & $358^{\mathrm{a}, \mathrm{B}}$ & 37 & $495^{\mathrm{b}, \mathrm{c}, \mathrm{B}}$ & 30 & $754^{\mathrm{d}, \mathrm{B}}$ & 35 & $508^{\mathrm{c}, \mathrm{B}}$ & 18 & $402^{\mathrm{a}, \mathrm{b}, \mathrm{B}}$ & 29 \\
\hline $\mathrm{DI}$ & $109^{a, A}$ & 11 & $144^{\mathrm{b}, \mathrm{A}}$ & 11 & $186^{\mathrm{c}, \mathrm{A}}$ & 11 & $138^{\mathrm{a}, \mathrm{A}}$ & 10 & $121^{\mathrm{a}, \mathrm{A}}$ & 5 \\
\hline \multicolumn{11}{|l|}{ Lipase } \\
\hline $\mathrm{Pl}$ & $256^{a, C}$ & 3 & $318^{\mathrm{b}, \mathrm{C}}$ & 5 & 400 & $10^{\mathrm{c}, \mathrm{C}}$ & $325^{\mathrm{b}, \mathrm{C}}$ & 8 & $276^{a, c}$ & 8 \\
\hline MI & $130^{\mathrm{a}, \mathrm{B}}$ & 3 & $137^{\mathrm{a}, \mathrm{B}}$ & 3 & 153 & $4^{\mathrm{b}, \mathrm{B}}$ & $138^{\mathrm{a}, \mathrm{B}}$ & 4 & $131^{\mathrm{a}, \mathrm{B}}$ & 1 \\
\hline DI & $37^{\mathrm{a}, \mathrm{A}}$ & 1 & $38^{\mathrm{a}, \mathrm{A}}$ & 3 & 53 & $2^{\mathrm{b}, \mathrm{A}}$ & $37^{\mathrm{a}, \mathrm{A}}$ & 1 & $41^{\mathrm{a}, \mathrm{A}}$ & 2 \\
\hline \multicolumn{5}{|l|}{ Regression } & \multicolumn{4}{|c|}{$R^{2}$} & \multicolumn{2}{|l|}{$P$} \\
\hline \multicolumn{5}{|l|}{ PI: $Y_{\text {chymotrypsin }}=-1.273 x^{2}+4.404 x+0.153$} & \multicolumn{4}{|c|}{0.868} & \multicolumn{2}{|c|}{$<0.001$} \\
\hline \multicolumn{5}{|l|}{ MI: $Y_{\text {chymotrypsin }}=-1.396 x^{2}+4.552 x-0.819$} & \multicolumn{4}{|c|}{0.863} & \multicolumn{2}{|c|}{$<0.001$} \\
\hline \multicolumn{5}{|l|}{ DI: $Y_{\text {chymotrypsin }}=-0.632 x^{2}+2.122 x-0.508$} & \multicolumn{4}{|c|}{0.722} & \multicolumn{2}{|c|}{$<0.05$} \\
\hline \multicolumn{5}{|l|}{ PI: $Y_{\text {trypsin }}=-0.567 x^{2}+2.017 x+1.053$} & \multicolumn{4}{|c|}{0.796} & \multicolumn{2}{|c|}{$<0.001$} \\
\hline \multicolumn{5}{|l|}{ Ml: $Y_{\text {trypsin }}=-0.56 x^{2}+1.870 x+0.341$} & \multicolumn{4}{|c|}{0.881} & $<0.0$ & \\
\hline DI: $Y_{\text {trypsin }}=-0.074 x^{2}+0.245 x-0.098$ & & & & & & & & & $<0.0$ & \\
\hline PI: $Y_{\text {amylase }}=-233.5 x^{2}+779.5 x+628.5$ & & & & & & & & & $<0 . c$ & \\
\hline MI: $Y_{\text {amylase }}=-282.6 x^{2}+913.4 x-92.88$ & & & & & & & & & $<0 . c$ & \\
\hline DI: $Y_{\text {amylase }}=-55 \cdot 19 x^{2}+178 \cdot 1 x+23 \cdot 27$ & & & & & & & & & $<0.0$ & \\
\hline $\mathrm{PI}: Y_{\text {lipase }}=-108 \cdot 4 x^{2}+351 \cdot 8 x+83 \cdot 92$ & & & & & & & & & $<0.0$ & \\
\hline MI: $Y_{\text {lipase }}=-17 \cdot 10 x^{2}+54 \cdot 91 x+102 \cdot 1$ & & & & & & & & & $<0.6$ & \\
\hline DI: $Y_{\text {lipase }}=-11 \cdot 3 x^{2}+36 \cdot 71 x+17 \cdot 29$ & & & & & & & & & $<0$. & \\
\hline
\end{tabular}

a,b,c,d Mean values within a row with unlike superscript letters were significantly different $(P<0.05)$

$\mathrm{A}, \mathrm{B}, \mathrm{C}$ Mean values within a column with unlike superscript letters were significantly different $(P<0.05)$

$\left.\mathrm{Y}_{\mathrm{IGF-I}}=-1 \cdot 146 x^{2}+3.793 x-1.439, \quad R^{2} 0.755, \quad P=0.007\right)$.

Based on the quadratic equations, the optimum Thr levels for the relative mRNA expression levels of $T O R, 4 E-B P 2$ and $I G F-I$ were $1 \cdot 66,1 \cdot 27$ and $1.65 \%$, respectively.

\section{Discussion}

Animal growth depends on nutrient digestion and absorption, which is governed by the activities of digestive enzymes and absorptive mechanisms ${ }^{(45)}$. Moreover, it depends on intestinal development. In our previous study, dietary Thr supplementation improved the growth, feed utilisation efficiency and protein retention of juvenile blunt snout bream, and the requirement for juvenile blunt snout was estimated to be $1.57 \%$ of the diet, corresponding to $4.62 \%$ of dietary protein ${ }^{(5)}$. In the present study, the HW, HSI and HPC were enhanced with increasing $\mathrm{Thr}$ levels up to $1.58 \%$, which suggested that $\mathrm{Thr}$ supplementation improved the growth and development of the hepatopancreas in juvenile blunt snout bream. This is consistent with the trends of growth performances demonstrated in our previous study ${ }^{(5)}$. Similar results were also reported in the hepatopancreas of Jian carp fed with graded levels of dietary $\mathrm{Thr}^{(28)}$. However, further studies are needed to evaluate the specific mechanisms by which Thr improved the growth of the hepatopancreas in fish. Moreover, in our previous study, the deficiency (0.58\%) and excess $(2.58 \%)$ of dietary Thr had a negative impact on the weight gain of blunt snout bream ${ }^{(6)}$. Similarly in the present study, imbalanced Thr levels (both 0.58 and 2.58\%) significantly reduced the HW, HSI and HPC in juvenile blunt snout bream, suggesting that an unbalanced Thr level could have adverse effects on the growth and development of the hepatopancreas. Nevertheless, specific mechanisms underlying the adverse effects of Thr-imbalanced diets on the growth and development of the hepatopancreas in fish need to be elucidated

A low-Thr diet reduced the gut weight of rats ${ }^{(27)}$ and the intestinal mass of piglets ${ }^{(46)}$. In the present study, the IW and ISI increased with increasing Thr levels up to $1.58 \%$, which could be related to the fact that Thr supplementation improved the intestinal growth and development of blunt snout bream. This is in agreement with the trends of growth performances demonstrated in our previous study ${ }^{(5)}$. Similar studies have considered the effects of $\mathrm{Thr}^{(28)}$, isoleucine ${ }^{(35)}$, lysine ${ }^{(47)}$, methionine ${ }^{(48)}$ and arginine ${ }^{(49)}$ on the growth and development of digestive organs in fish. Intestinal 


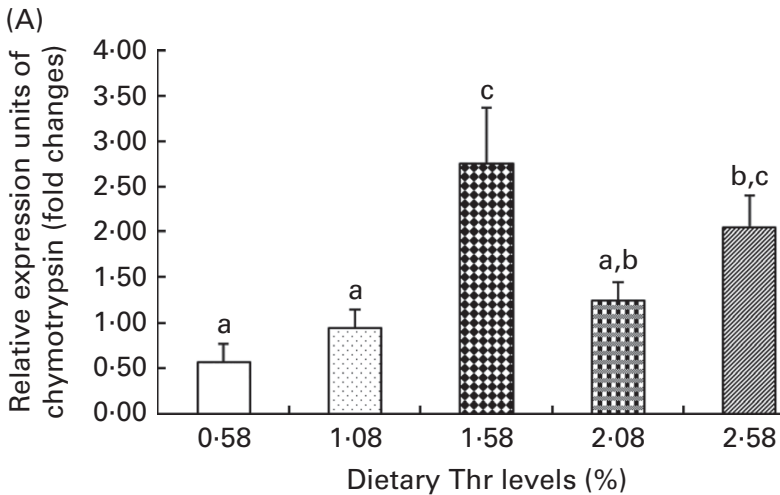

(C)

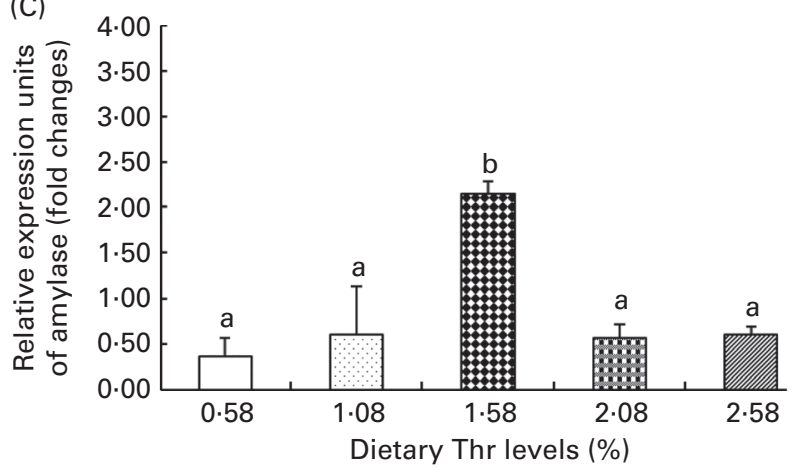

(B)

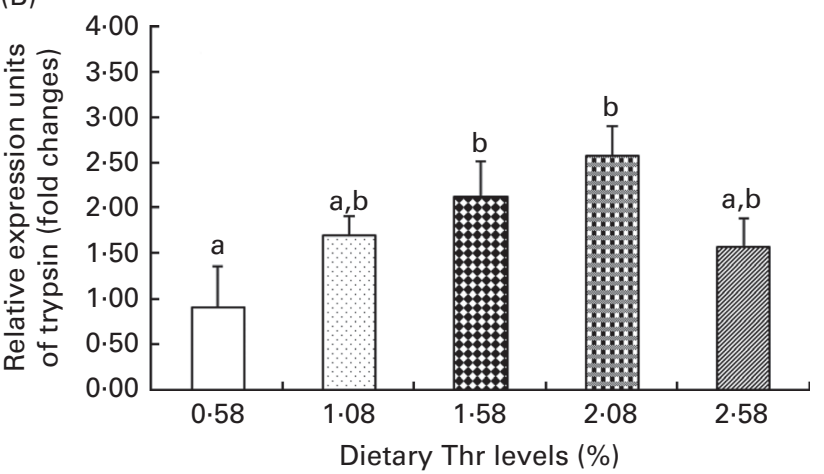

(D)

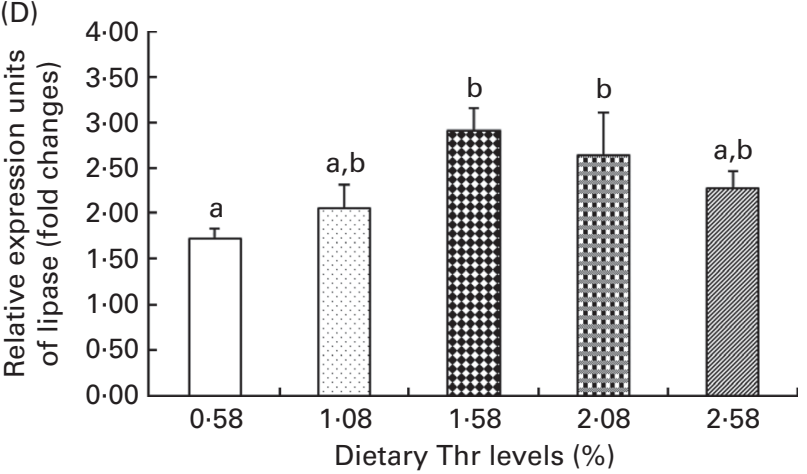

Fig. 1. Relative mRNA expression levels of (A) chymotrypsin, (B) trypsin, (C) amylase and (D) lipase in the hepatopancreas of juvenile blunt snout bream fed with the graded levels of dietary threonine (Thr) for 9 weeks. Values are means, with standard errors represented by vertical bars $(n 9)$. Mean values with unlike letters are significantly different $(P<0.05)$.

development is related to protein concentration in the intestinal tissue ${ }^{(50)}$. The present study showed that the IPC was improved by the supplementation of dietary Thr. Similarly, Thr increased the protein content of the intestine in Jian $\operatorname{carp}^{(28)}$ and the protein content of the jejunum in rats ${ }^{(27)}$. In our previous study, dietary $\mathrm{Thr}$ regulated the mRNA expression levels of the TOR pathway in the three intestinal segments of blunt snout bream ${ }^{(5)}$. An in vitro study has also indicated that the protein synthesis rate of enterocytes in the intestine was enhanced by $\mathrm{Thr}$ supplementation ${ }^{(28)}$. These studies suggested that Thr may enhance protein synthesis ability in fish as it does in terrestrial animals, and this important role of Thr in protein synthesis could be one of the primary causes of the improved growth and development of digestive organs. Moreover, in the present study, unbalanced Thr levels (both 0.58 and $2.58 \%$ ) significantly decreased the IW, ISI and IPC of juvenile blunt snout bream, suggesting that an imbalanced Thr level could have adverse effects on the growth and development of the intestine. Similarly in our previous study, a deficiency and an excess of Thr levels had a negative impact on the weight gain of blunt snout bream ${ }^{(6)}$.

In fish, digestive enzymes such as chymotrypsin, trypsin, amylase and lipase are synthesised in the exocrine pancreas and are secreted into the lumen of the intestine ${ }^{(51)}$. Digestive enzyme activities can directly reflect digestive ability ${ }^{(52)}$. In the present study, chymotrypsin, trypsin, amylase and lipase activities were significantly improved by the addition of $\mathrm{Thr}$ at an adequate (1.58\%) level in the hepatopancreas and intestinal segments, suggesting that dietary $\mathrm{Thr}$ at an adequate level could enhance the digestive ability of fish. The improved activities of digestive enzymes could be due to the improved growth of the hepatopancreas and the intestine by Thr in blunt snout bream. This is comparable with our previous study reporting that an optimum dietary Thr level improved the growth of blunt snout bream ${ }^{(5)}$. An adequate level of Thr also improved the digestive capacity and growth of Jian carp ${ }^{(28)}$. In the present study, different levels of chymotrypsin, trypsin, amylase and lipase activities were found between the three intestinal segments (PI, MI and DI), with the highest activities being observed in the PI followed by the MI. Similarly, the level of digestive enzyme activities differed between the gut sections, with all activities found to be significantly higher in the pyloric caecum compared with the foregut/ midgut and hindgut sections of yellowtail kingfish ${ }^{(53)}$. Nevertheless, this is the first report regarding the different activity levels of digestive enzymes (chymotrypsin, trypsin, amylase and lipase) between the PI, MI and DI in fish fed with dietary Thr, which needs to be elucidated.

Fish exocrine pancreas is the main site for the synthesis and secretion of digestive enzymes ${ }^{(51)}$. Digestive enzyme activity is known to be related to the synthesis and secretion of enzymes in fish ${ }^{(54)}$. The increased enzyme activity results from an increased synthesis of enzyme protein ${ }^{(32)}$, which is associated with gene transcription and translation ${ }^{(33)}$. In terrestrial animals, Thr participated in the amino acid composition of chymotrypsinogen, achymotrypsin and trypsinogen ${ }^{(55)}$, and was necessary for amylase synthesis in pigeon pancreas ${ }^{(56)}$. In the present study, Thr supplementation up-regulated the gene expression levels of digestive enzymes, such as chymotrypsin, trypsin, amylase and lipase in the hepatopancreas of blunt snout bream, 
(A)

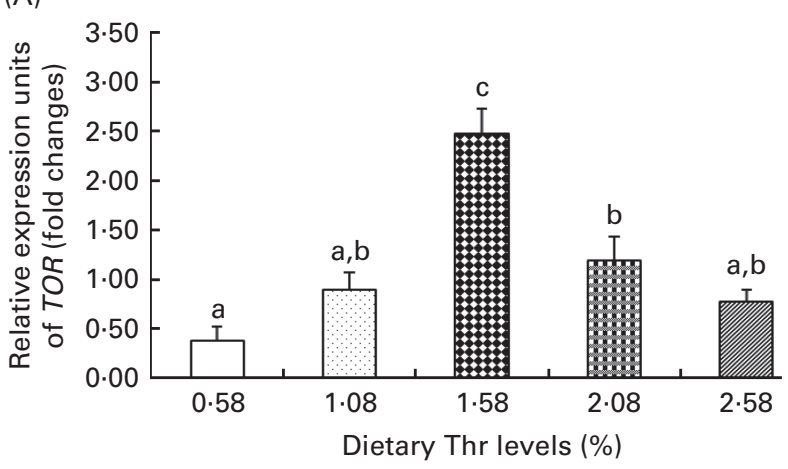

(B)

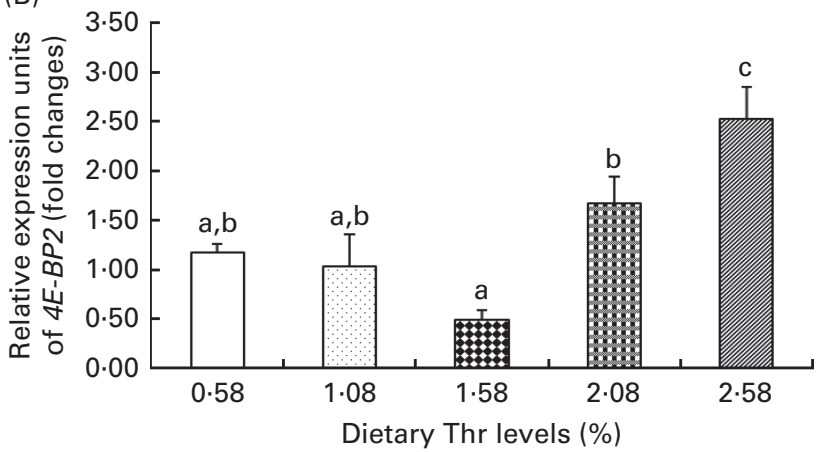

(C)

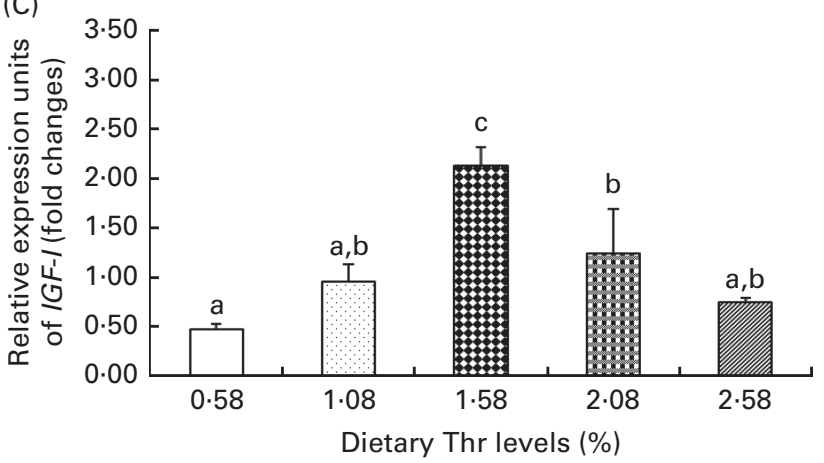

Fig. 2. Relative mRNA expression levels of (A) target of rapamycin (TOR), (B) eukaryotic translation initiation factor $4 \mathrm{E}$-binding protein $2(4 E-B P 2)$ and $(C)$ insulin-like growth factor-I (IGF-I) in the hepatopancreas of juvenile blunt snout bream fed with the graded levels of dietary threonine (Thr) for 9 weeks. Values are means, with standard errors represented by vertical bars $(n 9)$. Mean values with unlike letters are significantly different $(P<0.05)$.

which suggested that the beneficial effect of Thr on the activities of digestive enzymes may be partly related to the synthesis of enzymes in fish as it does in terrestrial animals. However, this is the first report about the effect of Thr on the gene expression levels of digestive enzymes in fish. Whether Thr supplementation improved the activities of digestive enzymes via regulating enzyme synthesis in fish needs to be elucidated.

The limiting step in protein synthesis is translation initiation, which is regulated by the TOR signalling pathway ${ }^{(30,57)}$. $4 \mathrm{E}-\mathrm{BP}$, a family of translational repressors, is a well-known target of TOR kinase and regulation of protein synthesis ${ }^{(58)}$. In the present study, dietary Thr modified the mRNA expression levels of $T O R$ and $4 E-B P 2$ in the hepatopancreas of juvenile blunt snout bream, which may go further to support the results of protein accretion improvement in this digestive organ. This is comparable with our previous study showing that dietary Thr modified the mRNA expression levels of TOR and $4 E-B P 2$ in the three intestinal segments of blunt snout bream ${ }^{(5,6)}$, and with another study conducted in the muscle, hepatopancreas and intestine of Jian carp ${ }^{(28)}$. Furthermore, the mRNA expression levels of $T O R$ in the hepatopancreas of blunt snout bream increased with increasing dietary Thr levels up to $1.58 \%$ and then decreased, while a reverse pattern was found in the mRNA expression levels of $4 E-B P 2$ in the present study, which is consistent with the trends of our previous study ${ }^{(5)}$.

Growth in fish and other vertebrates is under endocrine control, particularly through the growth hormone-IGF axis ${ }^{(59)}$. Insulin plays an important role in the regulation of protein synthesis ${ }^{(31)}$. In rats, IGF-I increased enterocyte proliferation ${ }^{(60)}$. Thr participates in the amino acid composition of IGF-I, and plays an important role in maintaining the structure of IGF-I ${ }^{(61)}$. In the present study, $1.58 \%$ dietary Thr up-regulated the mRNA expression levels of $I G F-I$ in the hepatopancreas of blunt snout bream, suggesting that an adequate level of Thr may regulate protein synthesis ability via regulating the IGF-I level in fish. However, this is the first study in fish and a specific mechanism remains to be elucidated. Meanwhile, a similar expression pattern was found between the mRNA expression levels of $I G F-I$ and TOR in the present study.

In conclusion, the present study showed that $1.58 \%$ dietary Thr improved the growth and development of the hepatopancreas and the intestine, and enhanced the activities of digestive enzymes in blunt snout bream. Dietary Thr regulated the mRNA expression levels of digestive enzymes (chymotrypsin, trypsin, amylase and lipase), TOR, $4 E-B P 2$ and $I G F-I$ in the hepatopancreas of juvenile blunt snout bream, which could explain further the positive effects of Thr supplementation on the digestion capacity, and the growth and development of digestive organs of this fish. The present study could provide a new molecular tool for studies on fish nutrition, and shed light on the regulatory mechanisms that dietary Thr enhanced digestive function in fish.

\section{Acknowledgements}

The authors gratefully acknowledge the postgraduate students of Fish Disease and Nutrition Department, FFRC, CAFS, Wuxi City, PR China for their help during the sampling period.

The present study was funded by grant from the Modern Agro-industry Technology Research System, PR China (grant no. CARS-46), the Special Fund for Agro-Scientific Research in the Public Interest (grant no. 201003020), and the National Nonprofit Institute Research Grant of FFRC, CAFS, PR China (grant no. 2014A08XK02). All funders had no role in the design and analysis of the study or in the writing of this article.

The authors' contributions are as follows: H.-M. H.-T., B. L., M. R., J. X. and X. G. designed the study; H.-M. H.-T., M. R., R. C., Q. Z. and L. P. performed the feeding trial and collected the sample; H.-M. H.-T., M. R. and B. L. analysed the data; H.-M. H.-T. wrote the manuscript; M. R., B. L. and X. G. provided advice and critical review of the manuscript. All authors read and approved the final version of the manuscript.

There are no conflicts of interest. 


\section{References}

1. Li XF, Liu WB, Jiang YY, et al. (2010) Effects of dietary protein and lipid levels in practical diets on growth performance and body composition of blunt snout bream (Megalobrama amblycephala) fingerlings. Aquaculture 303, 65-70.

2. Habte-Tsion HM, Liu B, Ge XP, et al. (2013) Effects of dietary protein levels on the growth performance, muscle composition, blood composition and digestive enzymes activities of Wuchang bream, Megalobrama amblycephala fry. Israeli J Aquacult 65, 1-9 (Bamidgeh 2014 IJA_65.925).

3. Ministry of Agriculture of the People's Republic of China (2013) China Fishery Statistical Yearbook. Beijing: Chinese Agricultural Press (in Chinese).

4. Zhou Z, Ren Z, Zeng H, et al. (2008) Apparent digestibility of various feedstuffs for blunt snout bream, Megalobrama amblycephala. Aquacult Nutr 4, 153-165.

5. Habte-Tsion HM, Liu B, Ren MC, et al. (2015) Dietary threonine requirement of juvenile blunt snout bream (Megalobrama amblycephala). Aquaculture 437, 304-311.

6. Habte-Tsion HM, Ge XP, Liu B, et al. (2015) A deficiency or an excess of dietary threonine level affects weight gain, enzyme activity, immune response and immune-related gene expression in juvenile blunt snout bream (Megalobrama amblycephala). Fish Shellfish Immunol 42, 439-446.

7. Ren MC, Liao YJ, Xie J, et al. (2013) Dietary arginine requirement of juvenile blunt snout bream, Megalobrama amblycephala. Aquaculture 414-415, 229-234.

8. Liao YJ, Ren MC, Liu B, et al. (2014) Dietary methionine requirement of juvenile blunt snout bream (Megalobrama amblycephala) at a constant dietary cystine level. Aquacult Nutr 20, 741-752.

9. Abidi SF \& Khan MA (2008) Dietary threonine requirement of fingerling Indian major carp, Labeo rohita (Hamilton). Aquacult Res 39, 1498-1505.

10. Bodin N, Mambrini M, Wauters JB, et al. (2008) Threonine requirements for rainbow trout (Oncorbynchus mykiss) and Atlantic salmon (Salmo salar) at the fry stage are similar Aquaculture 274, 353-365.

11. Gao YJ, Yang HJ, Liu YJ, et al. (2014) Effects of graded levels of threonine on growth performance, biochemical parameters and intestine morphology of juvenile grass carp Ctenopharyngodon idella. Aquaculture 424-425, 113-119.

12. Ronnestad I, Conceicao LEC, Aragao C, et al. (2000) Free amino acids are absorbed faster and assimilated more efficiently than protein in postlarval Senegal sole (Solea senegalensis). J Nutr 130, 2809-2812.

13. Ozorio ROA, Booms GHR, Huisman EA, et al. (2002) Changes in amino acid composition in the tissues of African catfish (Clarias gariepinus) as a consequence of dietary L-cartinine supplements. J Appl Ichthyol 18, 140-147.

14. Nose T (1979) Summary report on the requirements of essential amino acids for carp. In Finfish Nutrition and Feed Technology, pp. 145-156 [JE Halver and K Tiews, editors]. Berlin: Heenemann.

15. Ravi J \& Devaraj KV (1991) Quantitative essential amino acid requirements for growth of Catla catla (Hamilton). Aquaculture 96, 281-289.

16. Alam MS, Teshima S, Koshio S, et al. (2003) Optimum dietary threonine level for juvenile Japanese flounder Paralichthys olivaceus. Asian Fish Sci 16, 175-184.

17. Ahmed I (2007) Dietary amino acid L-threonine requirement of fingerling Indian catfish, Heteropneustes fossilis (Bloch) estimated by growth and biochemical parameters. Aquacult Int 15, 337-350.
18. Ahmed I, Khan M \& Jafri AK (2004) Dietary threonine requirement of fingerling Indian major carp, Cirrbinus mrigala (Hamilton). Aquac Res 35, 162-170.

19. Hakim Y, Uni Z, Hulata G, et al. (2006) Relationship between intestinal brush border enzymatic activity and growth rate in tilapias fed diets containing $30 \%$ or $48 \%$ protein. Aquaculture 257, 420-428.

20. Tibaldi E, Hakim Y, Uni Z, et al. (2006) Effects of the partial substitution of dietary fish meal by differently processed soybean meals on growth performance, nutrient digestibility and activity of intestinal brush border enzymes in the European sea bass (Dicentrarchus labrax). Aquaculture 261, 182-193.

21. Yu HR, Ai QH, Mai KS, et al. (2012) Effects of dietary protein levels on the growth, survival, amylase and trypsin activities in large yellow croaker, Pseudosciaena Crocea R., larvae. Aquac Res 43, 178-186.

22. García-Gasca A, Galaviz MA, Gutiérrez JN, et al. (2006) Development of the digestive tract, trypsin activity and gene expression in eggs and larvae of the bullseye puffer fish Sphoeroides annulatus. Aquaculture 251, 366-376.

23. Perez-Casanova JC, Murray HM, Gallant JW, et al. (2006) Development of the digestive capacity in larvae of haddock (Melanogrammus aeglefinus) and Atlantic cod (Gadus morbua). Aquaculture 251, 377-401.

24. Le Floc'h N \& Sève B (2005) Catabolism through the threonine dehydrogenase pathway does not account for the high first-pass extraction rate of dietary threonine by the portal drained viscera in pigs. Br J Nutr 93, 447-456.

25. van der Schoor SRD, Wattimena DL, Huijmans J, et al. (2007) The gut takes nearly all: threonine kinetics in infants. $A m J$ Clin Nutr 86, 1132-1138.

26. Schaart MW, Schierbeek H, van der Schoor SR, et al. (2005) Threonine utilization is high in the intestine of piglets. J Nutr 135, 765-770.

27. Faure M, Moennoz D, Montigon F, et al. (2005) Dietary threonine restriction specifically reduces intestinal mucin synthesis in rats. J Nutr 135, 486-491.

28. Feng L, Peng Y, Wu P, et al. (2013) Threonine affects intestinal function, protein synthesis and gene expression of TOR in Jian carp (Cyprinus carpio var. Jian). PLOS ONE 8, e69974.

29. Anthony TG, Reiter AK, Anthony JC, et al. (2001) Deficiency of dietary EAA preferentially inhibits mRNA translation of ribosomal proteins in liver of meal-fed rats. Am J Physiol Endocrinol Metab 281, E430-E439.

30. Holz MK, Ballif BA, Gygi SP, et al. (2005) mTOR and S6K1 mediate assembly of the translation preinitiation complex through dynamic protein interchange and ordered phosphorylation events. Cell 123, 569-580.

31. Schmelzle T \& Hall MN (2000) TOR, a central controller of cell growth. Cell 103, 253-262.

32. Thoenen H, Kettlee R, Burkard W, et al. (1971) Neurally mediated control of enzymes involved in the synthesis of norepinephrine; are they regulated as an operational unit? Naunyn-Schmiedebergs Archiv für Pharmakologie 270, $146-160$.

33. Chang HR, Arsenijevic D, Vladoianu IR, et al. (1995) Fish oil enhances macrophage tumor necrosis factor-alpha mRNA expression at the transcriptional level. Metabolism $\mathbf{4 4}$, $800-805$.

34. Wang CF, Xie SQ, Zhu XM, et al. (2006) Effects of age and dietary protein level on digestive enzyme activity and gene expression of Pelteobagrus fulvidraco larvae. Aquaculture 254, 554-562.

35. Zhao J, Liu Y, Jiang J, et al. (2012) Effects of dietary isoleucine on growth, the digestion and absorption capacity 
and gene expression in hepatopancreas and intestine of juvenile Jian carp (Cyprinus carpio var. Jian). Aquaculture 368-369, 117-128.

36. Millamena OM, Bautista-Teruel MN, Reyes OS, et al. (1998) Requirements of juvenile marine shrimp, Penaeus monodon (Fabricius) for lysine and arginine. Aquaculture 164, 95-104

37. Alam MS, Teshima S, Koshio S, et al. (2004) Effects of supplementation of coated crystalline amino acids on growth performance and body composition of juvenile kuruma shrimp Marsupenaeus japonicus. Aquacult Nutr 10, 309-316.

38. FAO (2004) National Aquaculture Legislation OverviewChina. In National Aquaculture Legislation Overview (NALO) Fact Sheets, [M Spreij, editor]. Rome: FAO Fisheries and Aquaculture Department. http://www.fao.org/fishery/ legalframework/nalo_china/en\#tcNB0041

39. Bradford MM (1976) A rapid and sensitive method for the quantitation of microgram quantities of protein utilizing the principle of protein - dye binding. Anal Biochem $\mathbf{7 2}$, 248-254.

40. Hummel BCW (1959) A modified spectrophotometric determination of chymotrypsin, trypsin, and thrombin. Can J Biochem Physiol 37, 1393-1399.

41. Furne M, Hidalgo M, Lopez A, et al. (2005) Digestive enzyme activities in Adriatic sturgeon Acipenser naccarii and rainbow trout Oncorbynchus mykiss: a comparative study. Aquaculture 250, 391-398.

42. Gao ZX, Luo W, Liu H, et al. (2012) Transcriptome analysis and SSR/SNP markers information of the blunt snout bream (Megalobrama amblycephala). PLOS ONE 7, e42637.

43. Livak KJ \& Schmittgen TD (2001) Analysis of relative gene expression data using real-time quantitative PCR and the $2^{-\Delta \Delta C_{\mathrm{T}}}$ method. Methods 25, 402-408.

44. Zeitoun IH, Ullrey DE, Magee WT, et al. (1976) Quantifying nutrient requirements of fish. J Fish Res Board Can 33, $167-172$.

45. Klein S, Cohn SM \& Alpers DH (1998) The alimentary tract in nutrition. In Modern Nutrition in Health and Disease, pp. 605-630 [ME Shils, JA Olson, M Shike and AC Ross, editors]. Baltimore: Williams and Wilkins.

46. Stoll B (2006) Intestinal uptake and metabolism of threonine: nutritional impact. Adv Pork Prod 17, 257-263.

47. Zhou XQ, Zhao CR, Jiang J, et al. (2008) Dietary lysine requirement of juvenile Jian carp (Cyprinus carpio var. Jian). Aquacult Nutr 14, 381-386.

48. Tang L, Wang GX, Jiang J, et al. (2009) Effect of methionine on intestinal enzymes activities, microflora and humoral immune of juvenile Jian carp (Cyprinus carpio var. Jian). Aquacult Nutr 15, 477-483.

49. Chen GF, Feng L, Kuang SY, et al. (2012) Effect of dietary arginine on growth, intestinal enzyme activities and gene expression in muscle, hepatopancreas and intestine of juvenile Jian carp (Cyprinus carpio var. Jian). Br J Nutr 108, 195-207.

50. Goldspink DF, Lewis SEM \& Kelly FJ (1984) Protein synthesis during the developmental growth of the small and large intestine of the rat. Biochem J 217, 527-534.

51. Zambonino-Infante JL \& Cahu C (2001) Ontogeny of the gastrointestinal tract of marine fish larvae. Comp Biochem Physiol 130C, 477-487.

52. Wen ZP, Zhou XQ, Feng L, et al. (2009) Effect of dietary pantothenic acid supplement on growth, body composition and intestinal enzyme activities of juvenile Jian carp (Cyprinus carpio var. Jian). Aquacult Nutr 15, 470-476.

53. Bowyer JN, Qin JG, Adams LR, et al. (2012) The response of digestive enzyme activities and gut histology in yellowtail kingfish (Seriola lalandi) to dietary fish oil substitution at different temperatures. Aquaculture 368-369, 19-28.

54. Beccaria C, DiazJP, Connes R, et al. (1991) Organogenesis of the exocrine pancreas in the sea bass, Dicentrarchus labrax L., reared extensively and intensively. Aquaculture 99, 339-354.

55. Smith MH (1966) The amino acid composition of proteins. $J$ Theoret Biol 13, 261-281.

56. Hokin LE (1951) Amino-acid requirements of amylase synthesis by pigeon pancreas slices. Biochem J 50, 216-220.

57. Wang X \& Proud CG (2006) The mTOR pathway in the control of protein synthesis. Physiology 21, 362-369.

58. Anand P \& Gruppuso PA (2006) Rapamycin inhibits liver growth during refeeding in rats via control of ribosomal protein translation but not cap-dependent translation initiation. J Nutr 136, 27-33.

59. Picha ME, Turano MJ, Beckman BR, et al. (2008) Endocrine biomarkers of growth and applications to aquaculture: a minireview of growth hormone, insulin-like growth factor (IGF)-I, and IGF-binding proteins as potential growth indicators in fish. North Am J Aquacult 70, 196-211.

60. Dahly EM, Guo Z \& Ney DM (2002) Alterations in enterocyte proliferation and apoptosis accompany TPN-induced mucosal hypoplasia and IGF-I-induced hyperplasia in rats. J Nutr 132, 2010-2014.

61. Rinderknecht E \& Humbel RE (1978) The amino acid sequence of human insulin-like growth factor I and its structural homology with proinsulin. J Biol Chem 253, 2769-2776. 